lets and dosages, differently worded instructions (sometimes not in English) and may even be of different formulation or make-up. Its recommendation to physicians was intended to counter this trend.

BMA's advice is heartily endorsed by the Association of British Pharmaceutical Industry. British manufacturers estimate they lost $£ 75$ million last year to "parallel imports", bought from their overseas divisions and sold in Britain considerably below the standard British price. The price differentials are a consequence of the varied methods for regulating pharmaceutical companies in different countries. In Britain, overall profits are limited under the Pharmaceutical Prices Regulation Scheme, which specifies a target profit band for each company, based on capital expenditure. In other countries, prices or profits may be controlled individually for different products.

The European Court of Justice ruled in 1976 that parallel importing should be facilitated and that restrictions would be in breach of freedom of trade, but in 1980 an attempt by the commission to introduce a directive legitimizing parallel importing failed. The new pharmaceutical importers' association justifies its present imports by citing a British licences exemption order intended to apply "in circumstances in which small quantities of medicinal products are imported into the United employed, and also controls advertising

Kingdom for the treatment of particular patients".

Even though advertising of products imported under this order is illegal, the Department of Health has been unwilling to take action against infringements, fearing it would be dragged through the European Court. A new statutory instrument that will permit advertising of parallel imports and comply with the European Court's ruling while retaining some controls is now being finalized by the Department of Health and will be laid before Parliament in a few weeks' time.

A spokesman for the parallel importers accepted that British patients had in the past been dispensed products other than those their physicians intended, but said the association will encourage its members to "put their houses in order"'. Recently, some of its members were obliged to give an undertaking in the High Court to stop passing off as the UK version an imported Glaxo product with deliberately counterfeit packaging.

At issue now is whether a voluntary professional association such as BMA can make recommendations to its own members without contravening European law. BMA says it took full legal advice before making its recommendations to physicians and is confident of their legality. The question now seems likely to be answered in court, and BMA has halted its campaign until the issue is resolved to its satisfaction.

Tim Beardsley

\section{China in space}

\section{Triumph and martyrdom}

CHINA'S space planners last month released details of the setbacks and disasters suffered during the nine-year effort to put into synchronous orbit an "experimental" communications satellite. The satellite was successfully launched on 8 April, and inserted into its final orbit at $125^{\circ} \mathrm{E}$ on 16 April.

The admission on Chinese radio that a number of "scientific and technical workers" had "laid down their precious lives" during the development of the satellite was clearly intended as part of the current drive against "anti-intellectual" prejudice still persisting from the Cultural Revolution.

The broadcast centred on two major examples of heroism. One, a lone martyr, Ma Jungyan, had been working on the possible effects of solar radiation on a satellite in orbit. As this was during the "chaotic time of the Gang of Four", $\mathrm{Ma}$ was obliged to carry out simulated experiments at the atomic energy research institute without even the "minimum safety protection". He was, said the commentator, fully aware of the danger but "knowing that there was a tiger in the mountains, he still headed towards them"'. As a result, he developed a serious radiation-induced lung condition, but during every remission continued to "work frantically",

The other incident was the explosion of a rocket on 28 January 1978, during tests on fuel flow. Seven of the research team, including the director of the test-pad, were seriously injured and several others suffered burns and ruptured eardrums. Nevertheless, at the urging of the injured director, a party meeting was held the same afternoon to determine the cause of the incident, and testing was back to normal three days later. A week after the incident, the director and "several other comrades" were back at work, still in bandages, and they returned to the hospital to complete their treatment only when the experiment was finished.

It is not clear whether there were any deaths in this incident; the commentator clearly implied, however, that there had been several fatalities on what he called the "battlefield" of the space programme, the programme of the rocketry division. Whether Ma Jungyan and his fellow martyrs will receive public recognition in the forthcoming exhibition on the Chinese space programme, which opens in Shanghai later this month, has not yet been revealed. But China seems bent on being open.

\section{Unesco Looking for signs of change}

FURTHER signs of the response of Unesco (the United Nations Educational, Scientific and Cultural Organization) to the discontent of some member states should become apparent next week, at the meeting of the organization's executive board arranged for 9-23 May. Those participating in the meeting expect that decisions about the budget for 1985 , when the US notice of withdrawal will have expired, cannot be taken until the meeting of the executive board due in November. But next week's meeting should throw some light on Unesco's response to the British Government's for radical changes in the organization's way of working.

The agenda for next week's meeting concern's Unesco's science and technology sector only in uncontroversial ways - the executive board is expected to take on the nod the secretariat's proposals for the invitation lists to this November's meeting on information technology and that planned for next year on problems affecting Latin America and the Caribbean. Moreover, science and technology are relatively well protected in the secretariat's proposals for trimming $\$ 10$ million from the two-year budget for 1984-85. Indeed, the grant to the International Council of Scientific Unions has actually been increased.

Fireworks, if there are any, will rather attend the general items on next week's agenda, especially that requiring a first response to the British letter from $\mathrm{Mr}$ Timothy Raison, Minister of State at the Overseas Development Administration, sent to the director-general of Unesco in March. That letter asked that Unesco should reorder its priorities and improve the management of its affairs. At a later meeting in London, the director-general was told that continued British membership "could not be justified" unless there were signs of change at Unesco.

By all accounts, few expect that there will be much that is tangible to report from this first meeting of the executive board since the letter was sent, although the British will at least be looking for some mechanism by which their proposals can be studied seriously. But the responses of both the Unesco secretariat and the delegates of other member states are likely also to influence the spirit in which the British Government carries out its promised - or threatened - review of the benefits of membership.

Mr Ray Beverton, who succeeded Sir John Kendrew on 1 April as chairman of the science and technology subcommittee of the British National Committee on Unesco, said earlier this week that his group had not yet begun work in earnest on the task, but that a meeting had been arranged for May. 